\title{
Identification of a Novel 2S Albumin with Antitryptic Activity from Caryocar brasiliense Seeds
}

\author{
Tiago Gonçalves Costa ${ }^{1}$, Octávio Luiz Franco ${ }^{1,2}$, Ludovico Migliolo ${ }^{1,2} \&$ Simoni Campos Dias ${ }^{1}$ \\ ${ }^{1}$ Centro de Análises Proteômicas e Bioquímicas, Universidade Católica de Brasília, Brasília, Brazil \\ ${ }^{2}$ Universidade Católica Dom Bosco, Campo Grande, Mato Grosso do Sul, Brazil \\ Correspondence: Simoni Campos Dias, Universidade Católica de Brasília, SGAN 916 Módulo B Avenida W5, \\ CEP: 70790-160, Brasília, DF, Brazil. Tel: 55-61-3448-7220. E-mail: si.camposdias@gmail.com
}

Received: March 5, 2015 Accepted: April 10, 2015 Online Published: May 15, 2015

doi:10.5539/jas.v7n6p197 URL: http://dx.doi.org/10.5539/jas.v7n6p197

\begin{abstract}
Proteinaceous and non-proteinaceous compounds with insecticidal activities have been isolated from plant sources. Here, protein extracts from Pequi seeds (Caryocar brasiliense) showed in vitro activity against trypsin-like enzymes. However, no activity was obtained against cancer cells, phytopathogenic fungi or human pathogenic bacteria. Further purification was performed by using trypsin-Sepharose affinity chromatography. Electrophoretic analysis revealed a single protein compound with molecular mass of approximately $14 \mathrm{kDa}$. Under reducing conditions, two peptides with smaller molecular masses were observed in SDS-PAGE, showing the presence of a heterodimeric peptide. MALDI-ToF/ToF sequencing was performed with a protein band removed from SDS-PAGE, and the sequence revealed high identity with the $2 \mathrm{~S}$ albumin family. Purified peptide was challenged in vitro against bovine trypsin and Spodoptera frugiperda digestive enzymes by using BApNA as a substrate, showing high inhibitory activity in both cases. Data here reported suggest that a $2 \mathrm{~S}$ albumin dimeric peptide could show biotechnological potential for S. frugiperda control. In summary, Cb2SA could be useful in controlling insect pests of agricultural interest.
\end{abstract}

Keywords: $2 \mathrm{~S}$ albumins, proteinase inhibitor, plant defense, Caryocar brasiliense

\section{Introduction}

The fall armyworm (S. frugiperda) is one of the most difficult pests to control in field corn, being efficiently controlled only when larvae are small. Although fall armyworm feeds primarily on corn, this insect pest is also capable of feeding on many crops, including alfalfa, cotton, peanuts, grasses, tobacco and several others (Oakeshott et al., 2013). On the other hand, several insecticidal compounds have been isolated from plant sources (Becker-Ritt \& Carlini, 2012; Coots, Lambdin, Grant, \& Rhea, 2013). Plants are able to synthesize numerous compounds that include secondary metabolites and proteinaceous compounds, and many of these compounds may be synthesized in the plant's defense system. Among such defensive proteins, some classes are notable for their activity against proteolytic enzymes, also known as proteinase inhibitors (Gomes et al., 2005). In this large group there are common proteinase inhibitor families, including the Kunitz-type inhibitors (Jongsma \& Bolter, 1997; Oliva et al., 2000), the Bowman-Birk class (Odani \& Ikenaka, 1973), the cyclotides MCoTI-I and MCoTI-I (Felizmenio-Quimio, Daly, \& Craik, 2001), thionins and vicilins, (Macedo, Andrade, Moraes, \& Xavier-Filho, 1993; Melo et al., 2002) and also 2S albumin proteins commonly found in storage seeds (Berrocal-Lobo et al., 2002).

$2 \mathrm{~S}$ albumins are water-soluble proteins widely distributed in dicot and monocot seeds, being considered one of the largest protein groups found in seed tissues, along with globulin (Berrocal-Lobo, et al., 2002). This protein was first isolated from soy (Glicine max) (Odani, Koide, \& Ono, 1987), and it is rich in cysteine, arginine, glutamine and asparagine (Koppelman et al., 2004; Monsalve, Villalba, Rico, Shewry, \& Rodríguez, 2007). Besides presenting anti-proteolytic activity (Kelly \& Hefle, 2000), 2S albumins can also present deleterious activity against fungi (Pelegrini et al., 2006; Ribeiro et al., 2011) and bacteria (Maria-Neto et al., 2011). Moreover, many of these proteins show biotechnological potential and might also work as emulsifiers (Burnett et al., 2002), as allergenics (Kelly \& Hefle, 2000) and, by interfering in blood calcium levels, acting as a calmodulin-antagonist (Polya, Chandra, \& Condron, 1993). 
In terms of structure, $2 \mathrm{~S}$ albumins may be composed of two polypeptide chains linked by two disulfide bridges, with short-chain of 3 to $5 \mathrm{kDa}$ and long-chain of about 8 to $10 \mathrm{kDa}$, both being encoded by the same gene (Koppelman et al., 2004; Pantoja-Uceda et al., 2004). Mature 2S albumin may be yielded from a post-translational process that involves a pro-peptide cleavage and formation of disulfide bonds in the vacuole (Hara-Nishimura, Shimada, Hatano, Takeuchi, \& Nishimura, 1998). Studies using Bertholletia excelsa demonstrated the presence of at least six $2 \mathrm{~S}$ albumin isoforms for the longer chain $(8.5 \mathrm{kDa})$ (Christophe et al., 1986).

In this context, this work aims to isolate and characterize a novel anti-proteolytic $2 \mathrm{~S}$ albumin from C. brasiliense seeds with biotechnological potential for the control of insect pests. This compound may be used to inhibit digestive enzyme activities in the insect pest by using transgenic plants or applying directly on crops, leading to insect death by starvation.

\section{Material and Methods}

\subsection{Extraction and Purification Procedures}

C. brasiliense seeds were acquired in a local market and were extracted. Approximately $100 \mathrm{~g}$ of seed flour was macerated using a blender, followed by continuous magnetic stirring with cold absolute acetone $(1: 10, \mathrm{w}: \mathrm{v})$ for $2 \mathrm{~h}$ at $4{ }^{\circ} \mathrm{C}$ to remove the oil ( $\mathrm{Li}$ et al., 2012). Acetone was removed and seed flour was air-dried for $2 \mathrm{~h}$ at room temperature. Tris- $\mathrm{HCl} 50 \mathrm{mM} \mathrm{pH} 7.5$ was subsequently added to the flour, and this mixture was placed in a magnetic stirrer for $12 \mathrm{~h}$ at $4{ }^{\circ} \mathrm{C}$, then being centrifuged for $30 \mathrm{~min}$ at $12,000 \mathrm{~g}$ at $4{ }^{\circ} \mathrm{C}$. The supernatant was collected and nominated $\mathrm{CE}$ (Crude Extract). CE was submitted to protein precipitation using acetone centrifuged for $30 \mathrm{~min}$ at $12,000 \mathrm{~g}$ at $4{ }^{\circ} \mathrm{C}$, desalted with column PD-10 G-25M Sepharose (GE Healthcare), lyophilized and re-suspended in Tris- $\mathrm{HCl} 50 \mathrm{mM}, \mathrm{pH}$ 7.5. Subsequently, the fraction collected was concentrated in speed vacuum and submitted to trypsin affinity chromatography, using the resin Sepharose 4B (SIGMA ALDRICH ${ }^{\circledR}$ ), following the manufacturer's instructions. For each $3.5 \mathrm{~mL}$ of resin prepared, $1 \mathrm{~g}$ of Sepharose 4B was used. The resin was re-suspended in $50 \mathrm{ml}$ of $1 \mathrm{mM} \mathrm{HCl}$ solution, washed, and vacuum filtered, and then added to $50 \mathrm{mM}$ $\mathrm{HCl}$ and allowed to stand for $15 \mathrm{~min}$. Trypsin was prepared by re-suspending $10 \mathrm{mg} \cdot \mathrm{mL}^{-1}$ of resin in $100 \mathrm{mM}$ sodium bicarbonate buffer, $\mathrm{pH} 8.3,500 \mathrm{mM} \mathrm{NaCl}$. The trypsin solution was then added to the resin, and this was allowed to stand for $16 \mathrm{~h}$ at $4{ }^{\circ} \mathrm{C}$. Excess trypsin was removed by thoroughly washing the column with five volumes of sodium bicarbonate buffer $\mathrm{pH} 8.3100 \mathrm{mM} \mathrm{NaCl} 500 \mathrm{mM}$. To block the remaining active groups, buffer was added to resin $100 \mathrm{mM}$ Tris- $\mathrm{HCl} \mathrm{pH} 8.0$ for $2 \mathrm{~h}$ and then washed with five volumes of $100 \mathrm{mM} \mathrm{HCl}$ solution, followed by another five volumes of buffer $50 \mathrm{mM}$ Tris- $\mathrm{HCl}, \mathrm{pH} 7.5$. The resin was then placed in a 10 $\mathrm{mL}$ vessel and equilibrated using the same buffer. During the chromatography, the absorbance was measured at $280 \mathrm{~nm}$. Subsequently, the retained protein fractions were collected into the $1.5 \mathrm{~mL}$ fraction and lyophilized for later in vitro assays. The Bradford method was used for protein quantification of all purification steps and assays, and bovine serum albumin (BSA) was used as protein standard (Bradford, 1976).

\subsection{Polyacrylamide Gel Electrophoresis}

Denaturant sodium dodecyl sulphate polyacrylamide gel electrophoresis (SDS-PAGE) was performed at $15 \%$ as described by Laemmli (Laemmli, 1970) at room temperature and also stained with silver nitrate (Blum, Beier, \& Gross, 1987).

\subsection{Preparation of the Insect Gut Proteinases}

S. frugiperda larvae were obtained from Centro Nacional de Recursos Genéticos e Biotecnologia (CENARGEN/EMBRAPA), Brasília, Brazil. Digestive proteinases were obtained after dissection and extraction of the guts (Terra, Ferreira, \& De Bianchi, 1977). The guts were surgically removed from the organisms and placed in an iso-osmotic saline $(150 \mathrm{mM} \mathrm{NaCl})$ solution. Gut tissue was stirred and centrifuged at $10,000 \mathrm{~g}$ at $4{ }^{\circ} \mathrm{C}$, for $10 \mathrm{~min}$. The supernatants were then recovered and used for in vitro assays. Additionally, all insect gut homogenates were prepared in Tris- $\mathrm{HCl} 50 \mathrm{mM}, \mathrm{pH}$ 7.5. The inhibitory activity was carried out according to the section below.

\subsection{Trypsin inhibitory Activity Assays}

Trypsin inhibitory activity was evaluated by using N-alpha-benzoyl-DL-arginine-p-nitroanilide BapNA (Erlanger, Kokowsky, \& Cohen, 1961). Aliquots of $10 \mu \mathrm{L}$ solution of bovine trypsin $\left(0.3 \mathrm{mg} \cdot \mathrm{mL}^{-1}\right.$ in $50 \mathrm{mM} \cdot \mathrm{L}^{-1} \mathrm{Tris}-\mathrm{HCl}$ buffer, $\mathrm{pH} 7.5$ ) were pre-incubated for $10 \mathrm{~min}$ at $37^{\circ} \mathrm{C}$ with $120 \mu \mathrm{L}$ of $2.5 \mathrm{mM} \cdot \mathrm{L}^{-1} \mathrm{HCl}$ solution and $365 \mu \mathrm{L}$ of $50 \mathrm{mM} \cdot \mathrm{L}^{-1}$ Tris- $\mathrm{HCl}$ buffer, $\mathrm{pH} 7.5$; a volume of $5 \mu \mathrm{L}$ containing different concentrations of fraction obtained from affinity chromatography was added $(151.3,115.7,80.1,62.3,44.5,35.6,26.7,17.8,8.9,5.34,1.78 \mu \mathrm{g})$. The reaction was started by adding $500 \mu \mathrm{L}$ of $1.25 \mathrm{mM} \cdot \mathrm{L}^{-1} \mathrm{BApNA}$. The reaction was continued for $15 \mathrm{~min}$ at 
$37^{\circ} \mathrm{C}$ and finished by adding $120 \mu \mathrm{L}$ of $30 \%$ acetic acid (v:v). The 4-nitroaniline generation was monitored in an OD $410 \mathrm{~nm}$. The values obtained allowed the IC50 (Inhibitory concentration for 50\% of enzymatic activity) to be identified. Positive controls were accomplished with the same method as described above, except without the addition of substrate. All assays were performed in triplicate. The calibration curve was obtained using diverse enzyme concentrations $\left(2.5,5.0,7.5,10,12.5,15,17.5\right.$ and $\left.20 \mu \mathrm{g} \cdot \mathrm{mL}^{-1}\right)$.

\subsection{Assays against Colorectal and Breast Cells}

Heterogeneous human epithelial colorectal adenocarcinoma (CACO-2), human breast cancer (MCF-7) and human colorectal carcinoma (HCT-116) cells were acquired from the Cell Bank in Rio de Janeiro (CR108). The cells were cultured in Dulbecco's Modified Eagle Medium (DMEM Gibco), supplemented with $10 \%$ fetal serum bovine, penicillin $\left(100 \mathrm{U} \cdot \mathrm{mL}^{-1}\right)$ and streptomycin $\left(100 \mu \mathrm{g} \cdot \mathrm{mL}^{-1}\right)$, and maintained at $37{ }^{\circ} \mathrm{C}$ in $\mathrm{CO}_{2}$ atmosphere $5 \%$ (Invitrogen, Burlington, ON, Canada). Evaluation of $\mathrm{Cb} 2 \mathrm{SA}$ effect against the tumor cells described above was assayed with $15 \mu \mathrm{g} \cdot \mathrm{mL}^{-1}$ final concentration. An MTT (3-(4,5-dimethylthiazol-2yl)-2,5-diphenyltetrazolium bromide) cytotoxicity test was used at $1 \mathrm{mg} \cdot \mathrm{mL}^{-1}$ to analyze the cell viability after incubation with samples for periods of 24, 48 and $72 \mathrm{~h}$. The cell culture assays were performed in triplicate.

\subsection{Antifungal Assays}

The MICs of Cb2SA were determined by using the medium microdilution method according to the Clinical and Laboratory Standards Institute (CLSI) M27-S3 (Wikler, Cockerill, Bush, Dudley, \& Eliopoulos, 2009) with RPMI 1640 medium. Stock Cb2SA solutions were dissolved in RPMI 1640 broth. The final concentrations ranged from 0.25 to $264 \mu \mathrm{g} \cdot \mathrm{mL}^{-1}$. Briefly, a standard inoculum of Fusarium oxysporum (Identification number 1042), Botrytis cinerea (Identification number 358), and Collestotrichum acutatum (Identification number 1933), Gilbertella persicaria (Identification number 1145), and Penicillium lividum (Identification number 244) were obtained from the phytopathogenic fungi collection of the Catholic University of Brasilia. Cellular density was adjusted at $530 \mathrm{~nm}$ wavelength to yield a fungal stock of $1 \times 10^{6} \mathrm{CFU} \cdot \mathrm{mL}^{-1}$. Further dilutions were performed with RPMI 1640 broth, resulting in a final inoculum of approximately $0.5 \times 10^{3}$ to $2.5 \times 10^{3}$ cells $\cdot \mathrm{mL}^{-1}$. Furthermore, $100 \mu \mathrm{L}$ of fungal suspension was incubated at $35^{\circ} \mathrm{C}$ and $100 \mu \mathrm{g}$ of the $\mathrm{Cb} 2 \mathrm{SA}$ was placed in the wells of the microdilution tray. End points were visually read after $72 \mathrm{~h}$. The MIC of Cb2SA was considered as the lowest concentration that caused complete growth inhibition (100\%) when compared to control tube growth. Each antifungal test was carried out in triplicate.

\subsection{Antibacterial Assays}

Staphylococcus aureus ATCC 25923 and Escherichia coli ATCC 8739 were used for antimicrobial assays. The bacterial species were cultured in $1.0 \mathrm{~mL} \mathrm{LB}$ broth for $2 \mathrm{~h}$, at $37^{\circ} \mathrm{C}$, in accordance with guidelines from the CLSI, 2009. The Cb2SA was incubated with $5 \times 10^{6} \mathrm{CFU} \cdot \mathrm{mL}^{-1}$ for each bacterial species for $4 \mathrm{~h}$, at $37^{\circ} \mathrm{C}$. The positive and negative assay controls were several dilutions of chloramphenicol and bacteria in LB medium, respectively. Bacterial growth was evaluated at $595 \mathrm{~nm}$, every hour within the incubation period, carried out according to protocols described by the National Committee for Clinical Laboratory Standards (NCLS) guidelines. All antibacterial experiments were carried out in triplicate. In addition, to determine the minimum inhibitory concentration (MIC), Cb2SA was serially diluted from 0.25 to $264 \mu \mathrm{g} \cdot \mathrm{mL}^{-1}$ in $\mathrm{LB}$ medium. MIC was determined as the lowest concentration that produced complete growth inhibition (100\%) in comparison to the negative control. In an individual well of a 96-well polypropylene plate, $100 \mu \mathrm{L}$ of each dilution (medium + peptide) and $10 \mu \mathrm{L}$ of cell suspension of bacteria were added (approximately $5 \times 10^{6} \mathrm{CFU}$ of bacteria). The plates were kept for $12 \mathrm{~h}$ at $37{ }^{\circ} \mathrm{C}$. During this period, the absorbance was read in a plate reader (Bio-Rad 680 Microplate Reader) at $595 \mathrm{~nm}$ every $30 \mathrm{~min}$.

\subsection{MALDI-ToF de novo Sequencing}

The partial sequence of Cb2SA was determined by using MALDI-ToF MS/MS analysis (AutoFlex, Bruker Daltonics, Billerica, MA). The fraction corresponding to the Cb2SA in SDS-PAGE 15\% (see above) was digested in gel by porcine trypsin (Trypsin Gold Mass Spectrometry Grade - Promega ${ }^{\circledR}$ ). To the dried gel pieces, a solution of trypsin was added $\left(0.033 \mu \mathrm{g} \cdot \mu \mathrm{L}^{-1}\right)$ in a minimal volume to cover the gel, and these suspensions were kept in an ice bath for $30 \mathrm{~min}$. A $40 \mu \mathrm{L}$ volume of ammonium carbonate $\left(50 \mathrm{mM} \cdot \mathrm{L}^{-1}\right)$ solution was added, and the system was incubated for $19 \mathrm{~h}$ at $37{ }^{\circ} \mathrm{C}$ (Shevchenko, Wilm, Vorm, \& Mann, 1996). For MALDI-MS analysis, $\alpha$-cyano-4-hydroxycinnamic acid (CHCA) at $50 \mathrm{mM} \cdot \mathrm{L}^{-1}$ in $0.3 \%$ aqueous acetonitrile was employed as a matrix. The peptides obtained by Cb2SA hydrolyses were mixed with ACHC ( $\alpha$-cyano-hydroxycinnamic acid) in a proportion of 1:3 (v:v) and deposited on to an AnchorChip ${ }^{\text {TM }}$ target (Bruker Daltonics, Bilerica, USA) and allowed to crystallize at room temperature. The ionization was performed in the positive reflected mode. Data were recorded in the $\mathrm{m} / \mathrm{z}$ range from 600 to 4,000 . Peptide fragmentation was conducted by LIFT methodology 
(Suckau et al., 2003). Spectrum interpretation and peptide sequencing were manually performed by using FlexAnalysis 3.4 software (Bruker Daltonics, Billerica, USA).

\subsubsection{In silico Alignment Analyses}

The peptide sequence generated was examined and compared to database protein sequences deposited in the NCBI (National Center for Biotechnology Information, http://www.ncbi.nlm.nih.gov) using the BLASTp search tool (Altschul et al., 1997) with a set to search in a database of plants (taxid: 3193), using the program defaults. The sequences obtained were compared by using the multiple alignment program ClustalW, with matrix BLOSSUM (Thompson, Higgins, \& Gibson, 1994) standard default (Weight Matrix - Blossum; Penalty for opening GAP - 10.0; penalty extension GAP - 0.2, hydrophobic residues - GPSNDQERK; percentage identity for delay - 30 and distance separation GAP - 8).

\section{Results}

\subsection{S Albumin Isolation}

Initially, the seed proteins were extracted and submitted to G-25M column P10 desalting to minimize the presence of carbohydrates and other interfering compounds (data not shown). The protein fraction was applied onto an affinity chromatograph using a trypsin-Sepharose column. The $2 \mathrm{~S}$ albumin bound to immobilized trypsin, being released after elution buffer application. $\mathrm{CE}$ was separated in non-retained and retained fractions, and the latter were eluted with $100 \mathrm{mM} \mathrm{HCl}$ (Figure 1A). These fractions were pooled and evaluated by $15 \%$ SDS-PAGE (Figure 1B). Gel was performed by using a sample buffer containing $\beta$-mercaptoethanol and another without $\beta$-mercaptoethanol. In the absence of $\beta$-mercaptoethanol a single band with $14 \mathrm{kDa}$ was observed (Figure 1B, Lane 1). In contrast, $\beta$-mercaptoethanol treatment caused a dissociation of the proteinaceous compound in two smaller polypeptide chains (probably 9 and $5 \mathrm{kDa}$ ) (Figure 1B, Lane 2). The inhibitor was ineffective against fungi and bacteria, not demonstrating deleterious activities against microbial growth. Moreover, no activity against cancer cells was noted.

(A)

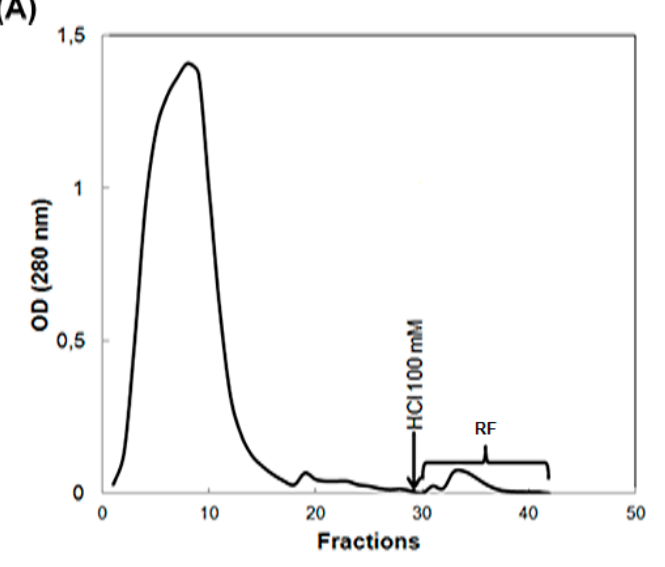

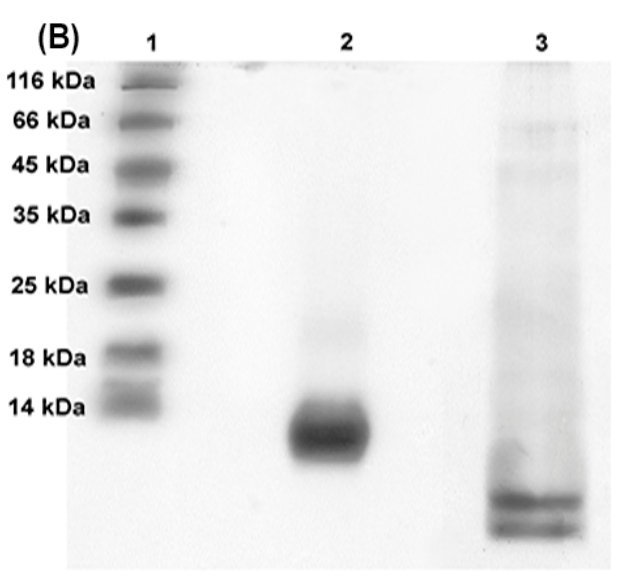

Figure 1. (A) Affinity chromatography of crude extract of Pequi using trypsin-sepharose resin. As a buffer, 50 $\mathrm{mM}$ Tris- $\mathrm{HCl} \mathrm{pH} 7.5$ was used, flow rate of $5 \mathrm{~mL} \cdot \mathrm{min}^{-1}$. Absorbance was monitored at $280 \mathrm{~nm}$. After reaching the absorbance values of $0.002,100 \mathrm{mM} \mathrm{HCl}$ was used as eluant. RF indicates the retained fraction collected. (B)

Gel 15\% SDS-PAGE using $50 \mu \mathrm{g}$ of the fraction retained from the trypsin-Sepharose column. (2) Fraction

prepared on reducing condition, using sample buffer with $\beta$-mercaptoethanol. (3) fraction prepared on non-reducing condition, using sample buffer without $\beta$-mercaptoethanol. The gel was stained using Coomassie Blue. (1) indicates the molecular marker

\section{2 de novo Sequencing by MALDI-ToF/ToF}

Mass spectrometry analyses were performed by using trypsinized protein bands from SDS-PAGE $15 \%$ (Shevchenko, Tomas, Havlis, Olsen, \& Mann, 2006). The spectrum analysis indicated various proteinaceous fragments obtained by tryptic digestion, and a fragment obtained after Cb2SA proteolysis was chosen for de novo sequencing. This fragment presented a major ion of $1395.62 \mathrm{Da}$ (Figure 2) selected due to high intensity. Through FlexAnalysis v3.4 software, the fragment was partially sequenced, and the $\mathrm{y}$ and $\mathrm{b}$ series were 
identified. The primary sequence obtained from Met-Ala-Glu-Asp-(Ile/Leu)-Pro-Ser from sequencing was compared with the NCBI protein database.

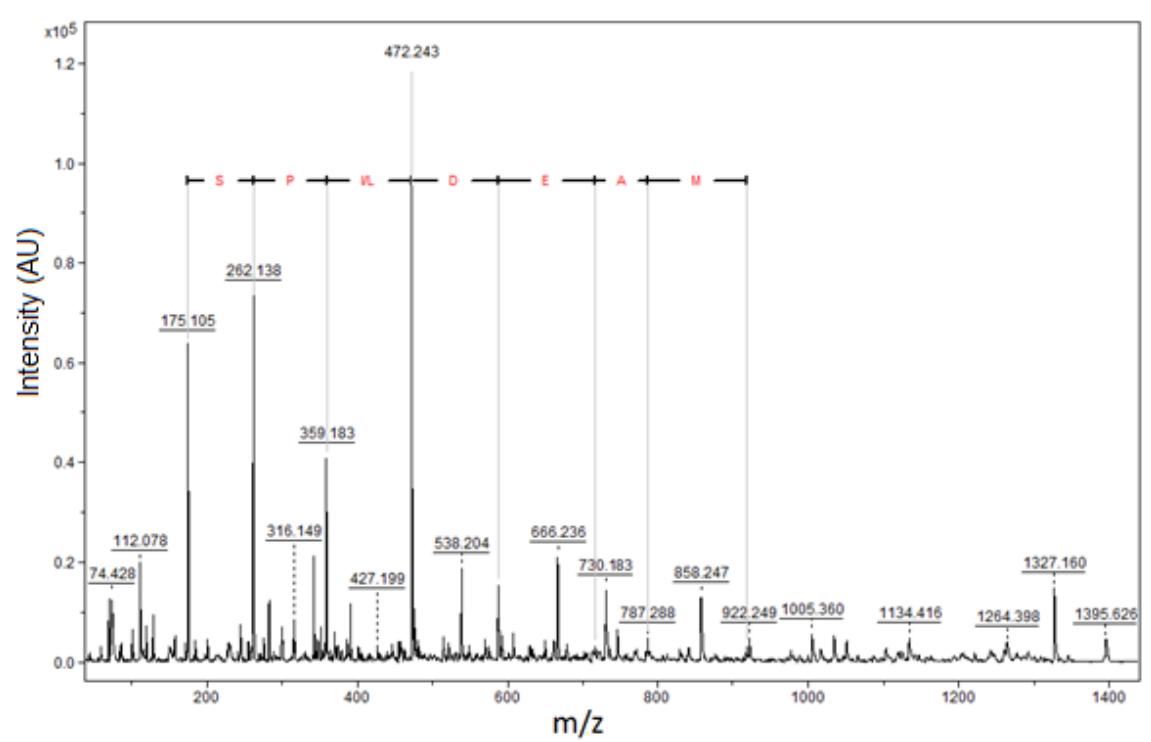

Figure 2. De novo sequencing of peptide was generated by mass spectrometer LIFT after SDS-Page trypsinization band. The fragment observed represents the mass $1395.62 \mathrm{Da}$ and the series of $y$ was determined by FlexAnalysis 3.6 version

The sequence achieved from MS showed higher identity with the peptide motif of $2 \mathrm{~S}$ albumin proteins isolated from B. excelsa (ACI70206.1) (Table 1). This peptide obtained from C. brasiliense was named Cb2SA.

Table 1. Multiple alignment among different isoforms of $2 \mathrm{~S}$ albumin with storage and allergenic function. Letters in red and green are considered identical and similar amino acids, respectively

\begin{tabular}{llllll}
\hline Accession Number & Alignment & Species & Identity\% & Function & Reference \\
\hline BAA96554.1 & RRMMRLAENIPSRCNLSPM & B. excelsa & 88 & Storage and allergenic & (Yamauchi, 2002) \\
ACI70207.1 & RRMMRLAENIPSRCNLSPM & B. excelsa & 88 & Storage and allergenic & (Altenbach et al., 1992) \\
Cb2SA & ---------MAEDLPSR---------- & C. brasiliense & - & Storage and defense & This report \\
ACI70206.1 & RMMMRMAENLPSRCNLSPQ & B. excelsa & 100 & Storage and allergenic & (Altenbach et al., 1992) \\
\hline
\end{tabular}

\subsection{S Albumin Functional Characterization}

After identification, the $2 \mathrm{~S}$ albumin-rich fraction was evaluated against fungi, bacteria, tumor cells and erythrocytes, not showing any activity (data not shown). However, purified Cb2SA was able to inhibit bovine trypsin completely at a concentration of $15 \mu \mathrm{g} \cdot \mathrm{mL}^{-1}$ (Figure 2). Moreover, Cb2SA was capable of completely inhibiting digestive trypsin-like enzymes from S. frugiperda by using $17 \mu \mathrm{g} \cdot \mathrm{mL}^{-1}$ (Figure 3). The values obtained allowed us to identify the IC50, a value of $11 \mu \mathrm{g} \cdot \mathrm{mL}^{-1}$. 


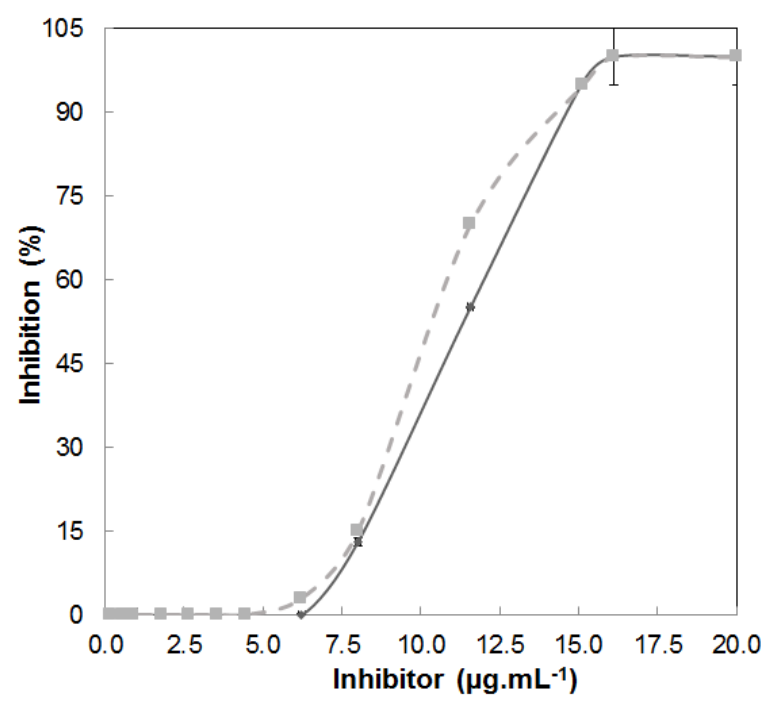

Figure 3. Inhibition curve of Cb2SA against bovine trypsin using BApNA as substrate (Continuous line) and inhibition curve of trypsin-like enzyme of S. frugiperda using BApNA as substrate (Dashed line). Values of 0.18, $0.53,0.89,1.78,2.67,3.56,4.45,6.23,8.01,11.57,15.13,16.13$ and $20 \mu \mathrm{g} \cdot \mathrm{mL}^{-1}$ of Cb2SA were used in both assays. The inhibition of bovine trypsin and trypsin-like enzyme of $S$. frugiperda started at 13.07 and 6.23 $\mu \mathrm{g} \cdot \mathrm{mL}^{-1}$ respectively. Vertical bars indicate the standard deviation

\section{Discussion}

Sequencing and electrophoretic analysis using sample buffer with and without $\beta$-mercaptoethanol corroborated the identification of $\mathrm{Cb} 2 \mathrm{SA}$ as a $2 \mathrm{~S}$ albumin. This class of protein is commonly synthesized as a single-chain precursor and undergoes the post-translational process in the vacuole. This process consists of pro-peptide cleavage, disulfide bond formation within and between chains and cleavage of the polypeptide chain, yielding two polypeptide chains linked by two disulfide bridges (Pantoja-Uceda et al., 2004). These results converge with other 2S albumin protein isolates from Passiflora alata (Ribeiro et al., 2011) and Hellianthus annus (Pantoja-Uceda et al., 2004).

Although several $2 \mathrm{~S}$ albumins have been isolated, only a few members of this group have shown inhibitory activity toward proteolytic enzymes (Duarte, Pereira, Souza, \& Conceição, 2010; Mandal, Kundu, Roy, \& Mandal, 2002).

Studies using $2 \mathrm{~S}$ albumin isolated from black beans (Phaseolus vulgaris L.) showed their ability to inhibit bovine trypsin (Duarte et al., 2010). Furthermore, in assays against bovine trypsin using specific synthetic substrate TAME (N- $\alpha$-p-Tosyl-L-Arginine Methyl Ester), Mandal et al. (2002) determined that the activity of the precursor BjTI, isolated from Brassica juncea, was able to inhibit trypsin activity completely. Proportionately, the Cb2SA albumin isolated in this work was able to inhibit bovine trypsin of the same mass using $6 \mu \mathrm{g}$ of protein, with the specific BApNA as substrate.

Cb2SA showed significant results in in vitro assays. The results allowed the IC50 of Cb2SA against S. frugiperda proteinases and bovine trypsin to be defined as $11 \mu \mathrm{g} \cdot \mathrm{mL}^{-1}$ for both enzymes. These values approximate those of other proteins with anti-tryptic activity. For example, SKTI, a trypsin inhibitor belonging to the Kunitz family isolated from soybeans, showed IC50 of $8 \mu \mathrm{g} \cdot \mathrm{mL}^{-1}$ against bovine trypsin (Ribeiro, Cunha, Fook, \& Sales, 2010). The percentage inhibition using Cb2SA exceeds the potential of inhibiting Cicer arietinum trypsin inhibitor (CaTI), a trypsin inhibitor isolated from peas, which caused $73 \%$ inhibition of bovine trypsin and $78 \%$ inhibition of the digestive enzymes of $A$. grandis (Gomes et al., 2005).

$S$. frugiperda is responsible for severe losses in grain production. In Brazil, it is estimated that this species is responsible for losses of about $25 \%$ in corn, and millions of dollars are spent each year in chemical control (Melo et al., 2006). The results achieved in this study indicate that the possible application of Cb2SA on plantations, using transgenic plants or directly applying on crops, would result in a more efficient way to control $S$. frugiperda, requiring lower concentrations than CaTI (Gomes et al., 2005). This may lead to lower control costs, as well as minimizing any side effects from the use of chemical compounds.

The use of $2 \mathrm{~S}$ albumins in in vivo insecticidal assays is not very common despite their clear and potent activities. 
Currently, chemical compounds are widely used to control agricultural pests. The possibility of employing albumins in the control of such pests demands research into their use in transgenic plants, via gene expression or direct soil application, before it can become applicable in the field. Among albumins, the chain of albumin PA1 b, isolated from pea, presented in vivo activity in assays against Culex pipiens and Aedes aegyptii (Gressent, Da Silva, Eyraud, Karaki, \& Royer, 2011). Moreover, the BjTI isolated from mustard, when expressed in the plant, improved resistance to $S$. litura (Mandal et al., 2002). The results obtained using Cb2SA against microorganisms and cancer cells did not show positive results, although other studies have indicated $2 \mathrm{~S}$ albumins may have biotechnological potential against fungi and bacteria (Duarte et al., 2010; Maria-Neto et al., 2011; Pelegrini et al., 2006). A 2 S albumin with similarity to napin isolated from Brassica rapa showed deleterious activity against Bacillus cereus, Bacillus subtilis and Mycobacterium phlei (Ngai \& Ng, 2004). Another $2 \mathrm{~S}$ albumin (To-A1) isolated from Taraxacum officinale showed activity against the fungus Phytophthora infestans (Odintsova et al., 2010). The results obtained in our study indicate a specific activity of Cb2SA to inhibit trypsin-like enzymes.

In summary, data here reported show a novel $2 \mathrm{~S}$ albumin isolated from $C$. brasiliense with trypsin inhibitory activity against $S$. frugiperda digestive enzymes. These results represent a potential source of knowledge for future studies and alternatives in controlling insects of agricultural interest, eg. transgenic plants with resistance to pests or powerful new pesticides without adverse effects.

\section{References}

Altenbach, S. B., Kuo, C. C., Staraci, L. C., Pearson, K. W., Wainwright, C., Georgescu, A., \& Townsend, J. (1992). Accumulation of a Brazil nut albumin in seeds of transgenic canola results in enhanced levels of seed protein methionine. Plant Mol Biol, 18(2), 235-245. http://dx.doi.org/10.1007/BF00034952

Altschul, S. F., Madden, T. L., Schaffer, A. A., Zhang, J., Zhang, Z., Miller, W., \& Lipman, D. J. (1997). Gapped BLAST and PSI-BLAST: A new generation of protein database search programs. Nucleic Acids Research, 25(17), 3389-3402. http://dx.doi.org/10.1093/nar/25.17.3389

Becker-Ritt, A. B., \& Carlini, C. R. (2012). Fungitoxic and insecticidal plant polypeptides. Biopolymers, 98(4), 367-384. http://dx.doi.org/10.1002/bip.22097

Berrocal-Lobo, M., Segura, A., Moreno, M., Lopez, G., Garcia-Olmedo, F., \& Molina, A. (2002). Snakin-2, an antimicrobial peptide from potato whose gene is locally induced by wounding and responds to pathogen infection. Plant Physiology, 128(3), 951-961. http://dx.doi.org/10.1104/pp.010685

Blum, H., Beier, H., \& Gross, H. J. (1987). Improved silver staining of plant proteins, RNA and DNA in polyacrylamide gels. Electrophoresis, 8(2), 93-99. http://dx.doi.org/10.1002/elps.1150080203

Bradford, M. M. (1976). A rapid and sensitive method for the quantitation of microgram quantities of protein utilizing the principle of protein-dye binding. Analytical Biochemistry, 72, 248-254. http://dx.doi.org/10.1016/0003-2697(76)90527-3

Burnett, G. R., Rigby, N. M., Mills, E. N., Belton, P. S., Fido, R. J., Tatham, A. S., \& Shewry, P. R. (2002). Characterization of the emulsification properties of $2 \mathrm{~S}$ albumins from sunflower seed. Journal of Colloid and Interface Science, 247(1), 177-185. http://dx.doi.org/10.1006/jcis.2001.8093

Christophe, A., Jozef, D., Luiz, A. B. C., Maria José, A. M. S., Marc, M., \& Joël, V. (1986). The amino-acid sequence of the $2 \mathrm{~S}$ sulphur-rich proteins from seeds of Brazil nut (Bertholletia excelsa). European Journal of Biochemistry, 159(3), 597-601. http://dx.doi.org/10.1111/j.1432-1033.1986.tb09926.x

Coots, C., Lambdin, P., Grant, J., \& Rhea, R. (2013). Spatial and temporal distribution of residues of imidacloprid and its insecticidal 5-hydroxy and olefin and metabolites in eastern hemlock (Pinales: Pinaceae) in the southern appalachians. Journal of economic entomology, 106(6), 2399-2406. http://dx.doi.org/10.1603/ec13142

Duarte, M. S. L., Pereira, C. A. S., Souza, E. C. G., \& Conceição, L. L. (2010). Determination of the in vitro activity of trypsin inhibitors in beans (Phaseolus vulgaris L.) black, albumin and globulin (Vol. 21). Araraquara: Alimentos e Nutrição.

Erlanger, B. F., Kokowsky, N., \& Cohen, W. (1961). The preparation and properties of two new chromogenic substrates of trypsin. Archives of Biochemistry and Biophysics, 95(2), 271-278. http://dx.doi.org/10.1016/0003-9861(61)90145-x

Felizmenio-Quimio, M. E., Daly, N. L., \& Craik, D. J. (2001). Circular proteins in plants: solution structure of a novel macrocyclic trypsin inhibitor from Momordica cochinchinensis. Journal of Biological Chemistry, 276(25), 22875-22882. http://dx.doi.org/10.1074/jbc.M101666200 
Gomes, A. P. G., Barbosa, A. E., Macedo, L. L., Pitanga, J. C., Moura, F. T., Oliveira, A. S., ... Sales, M. P. (2005). Effect of trypsin inhibitor from Crotalaria pallida seeds on Callosobruchus maculatus (cowpea weevil) and Ceratitis capitata (fruit fly). Plant Physiology and Biochemistry, 43(12), 1095-1102. http://dx.doi.org/10.1016/j.plaphy.2005.11.004

Gomes, A. P. G., Dias, S. C., Bloch, C., Jr.;, Melo, F. R., Furtado, J. R. Jr., Monnerat, R. G., ... Franco, O. L. (2005). Toxicity to cotton boll weevil Anthonomus grandis of a trypsin inhibitor from chickpea seeds. Comparative Biochemistry and Physiology Part B: Biochemistry and Molecular Biology, 140(2), 313-319. http://dx.doi.org/10.1016/j.cbpc.2004.10.013

Gressent, F., Da Silva, P., Eyraud, V., Karaki, L., \& Royer, C. (2011). Pea Albumin 1 subunit b (PA1b), a promising bioinsecticide of plant origin. Toxins Basel Journal, 3(12), 1502-1517. http://dx.doi.org/10.3390/toxins3121502

Hara-Nishimura, I., Shimada, T., Hatano, K., Takeuchi, Y., \& Nishimura, M. (1998). Transport of storage proteins to protein storage vacuoles is mediated by large precursor-accumulating vesicles. Plant Cell, 10(5), $825-836$.

Jongsma, M. A., \& Bolter, C. (1997). The adaptation of insects to plant protease inhibitors. Journal of Insect Physiology, 43(10), 885-895. http://dx.doi.org/10.1016/s0022-1910(97)00040-1

Kelly, J. D., \& Hefle, S. L. (2000). 2S methionine-rich protein (SSA) from sunflower seed is an IgE-binding protein. Allergy, 55(6), 556-559. http://dx.doi.org/10.1034/j.1398-9995.2000.00498.x

Koppelman, S. J., Nieuwenhuizen, W. F., Gaspari, M., Knippels, L. M. J., Penninks, A. H., Knol, E. F., ... de Jongh, H. H. J. (2004). Reversible denaturation of brazil nut 2S albumin (Ber e1) and implication of structural destabilization on digestion by pepsin. Journal of Agricultural and Food Chemistry, 53(1), 123-131. http://dx.doi.org/10.1021/jf0491355

Laemmli, U. K. (1970). Cleavage of Structural Proteins during the Assembly of the Head of Bacteriophage T4. Nature, 227(5259), 680-685. http://dx.doi.org/10.1038/227680a0

Li, X., Du, Y., Wu, G., Li, Z., Li, H., \& Sui, H. (2012). Solvent extraction for heavy crude oil removal from contaminated soils. Chemosphere, 88(2), 245-249. http://dx.doi.org/10.1016/j.chemosphere.2012.03.021

Macedo, M. L. R., Andrade, A., L. B. S., Moraes, R. A., \& Xavier-Filho, J. (1993). Vicilin variants and the resistance of cowpea (Vigna unguiculata) seeds to the cowpea weevil (Callosobruchus maculatus). Comparative Biochemistry and Physiology Part C: Comparative Pharmacology, 105(1), 89-94. http://dx.doi.org/10.1016/0742-8413(93)90063-q

Mandal, S., Kundu, P., Roy, B., \& Mandal, R. K. (2002). Precursor of the inactive 2S seed storage protein from the Indian mustard Brassica juncea is a novel trypsin inhibitor. Charaterization, post-translational processing studies, and transgenic expression to develop insect-resistant plants. The Journal of Biological Chemistry, 277(40), 37161-37168. http://dx.doi.org/10.1074/jbc.M205280200

Maria-Neto, S., Honorato, R. V., Costa, F. T., Almeida, R. G., Amaro, D. S., Oliveira, J. T., ... Franco, O. L. (2011). Bactericidal activity identified in $2 \mathrm{~S}$ albumin from sesame seeds and in silico studies of structure-function The Protein Journal, 3010 3), 350. http://dx.doi.org/10.1007/s10930-011-9337-x

Melo, E. P. d., Fernandes, M. G., Degrande, P. E., Cessa, R. M. A., Salomão, J. L., \& Nogueira, R. F. (2006). Spatial distribution of plants infested with Spodoptera frugiperda (J. E. Smith) (Lepidoptera: Noctuidae) on corn crop. Neotropical Entomology, 35, 689-697.

Melo, F. R., Rigden, D. J., Franco, O. L., Mello, L. V., Ary, M. B., Grossi de Sa, M. F., \& Bloch, C. Jr. (2002). Inhibition of trypsin by cowpea thionin: characterization, molecular modeling, and docking. Proteins, 48(2), 311-319. http://dx.doi.org/10.1002/prot.10142

Monsalve, R. I., Villalba, M., Rico, M., Shewry, P. R., \& Rodríguez, R. (2007). The 2S albumin proteins. Plant Food Allergens. Blackwell Publishing Ltd.

Ngai, P. H., \& Ng, T. B. (2004). A napin-like polypeptide from dwarf Chinese white cabbage seeds with translation-inhibitory, trypsin-inhibitory, and antibacterial activities. Peptides, 25(2), 171-176. http://dx.doi.org/10.1016/j.peptides.2003.12.012

Oakeshott, J. G., Farnsworth, C. A., East, P. D., Scott, C., Han, Y., Wu, Y., \& Russell, R. J. (2013). How many genetic options for evolving insecticide resistance in heliothine and spodopteran pests? Pest Management 
Science, 69(8), 889-896. http://dx.doi.org/10.1002/ps.3542

Odani, S., \& Ikenaka, T. (1973). Studies on Soybean Trypsin Inhibitors. Journal of Biochemistry, 74(4), 697-715.

Odani, S., Koide, T., \& Ono, T. (1987). Amino acid sequence of a soybean (Glycine max) seed polypeptide having a poly(L-aspartic acid) structure. The Journal of Biological Chemistry, 262(22), 10502-10505.

Odintsova, T. I., Rogozhin, E. A., Sklyar, I. V., Musolyamov, A. K., Kudryavtsev, A. M., Pukhalsky, V. A., ... Egorov, T. A. (2010). Antifungal activity of storage $2 \mathrm{~S}$ albumins from seeds of the invasive weed dandelion Taraxacum officinale Wigg. Protein and Peptide Letters, 17(4), 522-529. http://dx.doi.org/10.2174/092986610790963591

Oliva, M. L. V., Souza-Pinto, J. C., Batista, I. F. C., Araujo, M. S., Silveira, V. F., Auerswald, E. A., ... Sampaio, C. A. M. (2000). Leucaena leucocephala serine proteinase inhibitor: primary structure and action on blood coagulation, kinin release and rat paw edema. Biochimica et Biophysica Acta (BBA) - Protein Structure and Molecular Enzymology, 1477(1-2), 64-74. http://dx.doi.org/10.1016/s0167-4838(99)00285-x

Pantoja-Uceda, D., Palomares, O., Bruix, M., Villalba, M., Rodriguez, R., Rico, M., \& Santoro, J. (2004). Solution structure and stability against digestion of rproBnIb, a recombinant $2 \mathrm{~S}$ albumin from rapeseed: relationship to its allergenic properties. Biochemistry, 43(51), 16036-16045. http://dx.doi.org/10.1021/bi048069x

Pantoja-Uceda, D., Shewry, P. R., Bruix, M., Tatham, A. S., Santoro, J., \& Rico, M. (2004). Solution structure of a methionine-rich $2 \mathrm{~S}$ albumin from sunflower seeds: relationship to its allergenic and emulsifying properties. Biochemistry, 43(22), 6976-6986. http://dx.doi.org/10.1021/bi0496900

Pelegrini, P. B., Noronha, E. F., Muniz, M. A., Vasconcelos, I. M., Chiarello, M. D., Oliveira, J. T., \& Franco, O. L. (2006). An antifungal peptide from passion fruit (Passiflora edulis) seeds with similarities to $2 \mathrm{~S}$ albumin proteins. Biochimica et Biophysica Acta, 1764(6), 1141-1146. http://dx.doi.org/10.1016/j.bbapap.2006.04.010

Polya, G. M., Chandra, S., \& Condron, R. (1993). Purification and sequencing of radish seed calmodulin antagonists phosphorylated by calcium-dependent protein kinase. Plant Physiology, 101(2), 545-551. http://dx.doi.org/10.1104/pp.101.2.545

Ribeiro, J. K., Cunha, D. D., Fook, J. M., \& Sales, M. P. (2010). New properties of the soybean trypsin inhibitor: Inhibition of human neutrophil elastase and its effect on acute pulmonary injury. European journal of pharmacology, 644(1-3), 238-244. http://dx.doi.org/10.1016/j.ejphar.2010.06.067

Ribeiro, S. M., Almeida, R. G., Pereira, C. A., Moreira, J. S., Pinto, M. F., Oliveira, A. C., ... Franco, O. L. (2011). Identification of a Passiflora alata Curtis dimeric peptide showing identity with $2 \mathrm{~S}$ albumins. Peptides, 32(5), 868-874. http://dx.doi.org/10.1016/j.peptides.2010.10.011

Shevchenko, A., Tomas, H., Havlis, J., Olsen, J. V., \& Mann, M. (2006). In-gel digestion for mass spectrometric characterization of proteins and proteomes. Nature protocols, 1(6), 2856-2860. http://dx.doi.org/10.1038/nprot.2006.468

Shevchenko, A., Wilm, M., Vorm, O., \& Mann, M. (1996). Mass spectrometric sequencing of proteins silver-stained polyacrylamide gels. Analytical Chemistry, 68(5), 850-858. http://dx.doi.org/10.1021/ac950914h

Suckau, D., Resemann, A., Schuerenberg, M., Hufnagel, P., Franzen, J., \& Holle, A. (2003). A novel MALDI LIFT-TOF/TOF mass spectrometer for proteomics. Analytical and Bioanalytical Chemistry, 376(7), 952-965. http://dx.doi.org/10.1007/s00216-003-2057-0

Terra, W. R., Ferreira, C., \& De Bianchi, A. G. (1977). Action pattern, kinetical properties and electrophoretical studies of an alpha-amylase present in midgut homogenates from Rhynchosciara americana (Diptera) larvae. Comparative Biochemistry and Physiology. B, Comparative Biochemistry, 56(2), 201-209. http://dx.doi.org/10.1016/0305-0491(77)90049-9

Wikler, M., Cockerill, F., Bush, K., Dudley, M., \& Eliopoulos, G. (2009). Methods for dilution antimicrobial susceptibility tests for bacteria that grow aerobically. Clinical and Laboratory Standards Institute.

Yamauchi, D. (2002). Brazil nut 2S albumin was synthesized in a transgenic French bean seed with a promoter of the gene for canavalin, 7S globulin from Canavalia gladiata. Plant Biotechnology Journal, 17, 4. 


\section{Copyrights}

Copyright for this article is retained by the author(s), with first publication rights granted to the journal.

This is an open-access article distributed under the terms and conditions of the Creative Commons Attribution license (http://creativecommons.org/licenses/by/3.0/). 